\title{
Economic Geography and Industrial Marketing Views on Trade Shows: Collective Marketing and Knowledge Circulation
}

\author{
Diego Rinallo, Harald Bathelt \& Francesca Golfetto
}

\author{
Version Post-print/accepted manuscript \\ Citation Rinallo, D., Bathelt, H., \& Golfetto, F. (2017). Economic geography and \\ (published version) industrial marketing views on trade shows: Collective marketing and \\ knowledge circulation. Industrial Marketing Management, 61, 93-103. \\ Copyright / License (C) 2011. This manuscript version is made available under the CC-BY- \\ NC-ND 4.0 license. \\ http://creativecommons.org/licenses/by-nc-nd/4.0/ \\ Publisher's Statement The version of record [Rinallo, D., Bathelt, H., \& Golfetto, F. (2017). \\ Economic geography and industrial marketing views on trade shows: \\ Collective marketing and knowledge circulation. Industrial Marketing \\ Management, 61, 93-103.] is available online at: \\ https://www.sciencedirect.com/science/article/pii/S0019850116301201 \\ [doi:10.1016/j.indmarman.2016.06.012]
}

How to cite TSpace items

Always cite the published version, so the author(s) will receive recognition through services that track citation counts, e.g. Scopus. If you need to cite the page number of the TSpace version (original manuscript or accepted manuscript) because you cannot access the published version, then cite the TSpace version in addition to the published version using the permanent URI (handle) found on the record page. 


\title{
Economic Geography and Industrial Marketing Views on Trade Shows: Collective Marketing and Knowledge Circulation
}

\author{
Diego Rinallo
}

Associate Professor, Marketing Department, Kedge Business School Affiliate Researcher, CERMES, Center of Research on Marketing and Services Associate Researcher, CERGAM, Centre d'Etudes et de Recherche en Gestation d'Aix-Marseille

Domaine de Luminy, BP 921

13288 Marseille Cedex 9, France

diego.rinallo@kedgebs.com

\section{Harald Bathelt}

Professor, Department of Geography and Department of Political Science

Sidney Smith Hall, 100 St.George Street

Toronto, ON M5S 3G3, Canada

harald.bathelt@utoronto.ca

Francesca Golfetto

Professor, Marketing Department

Affiliate Researcher, CERMES, Center of Research on Marketing and Services

Via Roentgen 1

20136 Milan, Italy

francesca.golfetto@unibocconi.it 


\section{Economic Geography and Industrial Marketing Views on Trade Shows: Collective Marketing and Knowledge Circulation}

\section{Introduction}

Trade shows are a well-established component of industrial marketers' promotional mix. Despite ongoing debates about the negative impact that the digitalization of promotional activities has had on the trade show industry, these events remain important promotional tools for firms operating in industrial markets (see Golfetto and Rinallo, 2012, for an overview). Research in the field of industrial marketing (IM) has mostly focused on how individual firms, preoccupied with the "exorbitant costs of exhibiting,' might select the best events, manage their participation effectively, and maximize returns on investments (Borghini et al., 2006; Hansen, 1996). In economic geography (EG), the literature that developed during the 2000s deviates in important respects from traditional IM approaches. It is based on a production perspective and builds on the local buzz and global pipeline model of cluster development to explore how firms in specialized industrial regions gain access to wider markets (Bathelt et al., 2004). This literature considers trade shows to be crucial events that enable local producers to link with non-local partners, for the purposes of gaining access to new markets and acquiring important information about technologies and production conditions in distant regional/national contexts. From this knowledge-based perspective, trade shows are conceived as temporary clusters where forms of organized proximity make it possible for firms to interact with and learn from geographically distant actors and, as a result, escape the negative aspects of embeddedness (Maskell et al., 2006). 
In this conceptual paper, we critically review the literature on trade shows in IM and EG. In so doing, we seek to contribute to the ongoing conversation between these two disciplines and show that they can productively learn from each other. We aim to highlight how studies in IM have influenced EG research and suggest specific ways in which an EG perspective could revitalize IM research on trade shows. From this perspective, IM literature can be criticized for undertheorizing space, downplaying the role of trade shows as platforms for resource interaction, and conceiving exhibitors as individual agents. In other words, it neglects the fact that many of these events are collective marketing platforms that industry agglomerations or geographical clusters can use to affirm their presence in international markets. Based on our analysis, we propose research directions that can benefit individual exhibitors as well as geographically based business networks. The analysis addresses the boundaries and limitations of disciplinary analyses and strongly suggests transdisciplinary encounters and engagements in IM and EG research.

This paper is structured as follows. In sections 2 and 3, we review the literature on trade shows in IM and EG with a comparative analysis that highlights key differences and emerging areas of convergence. Section 4 discusses the impact of IM on EG geography views on trade shows by showing how an understanding of these events as temporary marketplaces contributes to a better understanding of the role these events play in the globalizing knowledge economy. Section 5 identifies the prospects of integrating an EG perspective into IM studies by refining classic tools and theoretical perspectives and moving from an individualistic to a collective and even spatial understanding in the analysis of trade shows. This helps to identify the challenges and tasks of a future research agenda that is built on a comprehensive knowledge 
perspective. Section 6 summarizes the main arguments and makes a strong case for a transdisciplinary research agenda and methodology.

\section{Trade Shows in Industrial Marketing: A Brief Literature Review}

In this section, we briefly review IM scholarship on trade shows by highlighting the metaphors adopted, reasons for theoretical interest, concerns, theoretical underpinning, actors investigated, and emerging areas of convergence with EG literature (see Table 1). Trade shows are temporary marketplaces where suppliers from an industry or product group gather to showcase their products and services (Black, 1986) to current and potential buyers, the media, and other purchase influencers. Economists regard these events as transaction cost-saving institutions that, by bringing together (at the same time and in the same place) a large number of suppliers, reduce the time and cost associated with industrial buyers' purchasing processes (Florio, 1994). Literature on trade shows in IM has evolved independently from EG and as a whole can be said to pay limited attention to geographical structures and spatial relations.

\section{--- Insert Table 1 around here ---}

Marketing and management scholars started investigating trade shows in the late 1960s with the aim of providing guidance to industrial marketers concerned with the 'exorbitant cost of exhibiting' on how to make the most of these promotional tools (Banting and Blenkhorn, 1974; Bellizzi and Lipps, 1984; Bonoma, 1983; Carman, 1968; Cavanaugh, 1976; Kerin and Cron, 1987). Firms operating in industrial markets typically invest a large part of their promotional budget to exhibit at these events (Golfetto, 2004), which are particularly useful to contact industrial buyers in the key stages of the purchase process, where they evaluate alternative solutions, products, 
and suppliers (Gopalakrishna and Lilien, 1995; see also Deeter-Schmelz and Kennedy, 2002; Moriarty and Spekman, 1984; Parasuraman, 1981). As such, IM research has been focused on measuring and maximizing trade show results (see, among others, Dekimpe et al., 1997; Gopalakrishna and Lillien, 1995; Gopalakrishna and Williams, 1992; Gopalakrishna et al., 1995; Hansen, 2004; Herbig et al., 1993; Ling-yee, 2007, 2008; Sashi and Perretty, 1992; Seringhaus and Rosson, 2001; Shoham, 1999; Smith et al., 2004; Tanner, 2002; Williams et al., 1993).

By linking exhibitors' pre-show, show, and post-show activities to indicators of communication and sales performance, IM researchers sought to provide industrial marketers with empirical generalizations on best practices that maximize the outcomes of exhibitors' participation at trade shows. Initially focused on sales outcomes (such as generating leads or converting trade show contacts into orders), the increasingly sophisticated modeling literature has more recently adopted multidimensional measures of performance that highlight the role of these events in promoting brand image in industrial markets (e.g. Hansen, 2004). Building on previous accounts of exhibitor/visitor interaction at trade shows (Evers and Knight, 2008; Rice, 1992; Rosson and Seringhaus, 1995; Sarmento et al., 2015) theoretically grounded in the Industrial Marketing and Purchasing (IMP) research tradition (Ford, 1980; Ford et al., 1998; Håkansson, 1992; Håkansson et al., 2009), more recent work has moved beyond the initial emphasis on one-way promotional communication flows from exhibitors (industrial marketers) to visitors (industrial buyers) by highlighting that trade shows are events where firms learn from one another (Bettis-Outland et al., 2010, 2012; Borghini et al., 2006; Ling-yee, 2006; Rinallo et al., 2010).

While effectiveness issues have been a major preoccupation of IM scholarship on trade shows, other research streams have investigated appropriate goals for these 
events (Bonoma, 1983; O’Hara et al., 1993; Rosson and Seringhaus, 1995; Sharland and Balogh, 1996; Shipley et al., 1993; Shoham, 1992; Tanner and Chonko, 1995), the decision to participate in trade shows (Kijewski et al., 1993; Lilien, 1983), and the selection of trade shows (Bello and Barczak, 1990; Faria and Dickinson, 1985). From this perspective, visitor behavior is less often the object of analysis (Bello, 1992; Bello and Lothia, 1993; Blythe, 2002; Godar and O'Connor, 2001; Hansen, 1996, Rinallo et al., 2010), although visitors are generally of interest if they are members of buying centers, i.e. individuals with influence over their employers' purchase processes.

To date, trade show organizers (who design, produce, and market these events) have received scant attention in the IM literature. Munuera and Ruiz (1999) conceptualized trade shows as services and conducted a study on visitor behavior with the goal of providing organizers with managerial implications. More recently, Rinallo and Golfetto (2006) analyzed a French trade show organizer's strategy and highlighted that these events can be collective marketing platforms for the (often geographically bounded) industrial networks that support them. Through their industrial associations, these networks are often actively involved in their organization, as they realize the importance of trade show organizers' value-creation strategies for exhibitors' profitmaximizing practices (Golfetto et al., 2008; Rinallo et al., 2006).

In summary, IM literature on trade shows has mostly adopted a 'geography-free' approach. This is ironic, given the role these events play in industrial firms' internationalization and export promotion processes (Evers and Knight, 2008; O’Hara et al., 1993; Seringhaus and Rosson, 1994). Only in recent years has it become possible to identify lines of convergence between IM and EG research based on the attention given to these events as contexts where firms can learn from one another and 
as collective promotional tools for industrial networks. Even recent IM

conceptualizations undertheorize space and do not engage with literature in EG. In the following section, we introduce literature on trade shows from the perspective of Relational Economic Geography and highlight how key ideas and concepts from IM have enabled economic geographers to go beyond the limits of early formulations.

\section{Trade Shows in Economic Geography: Temporary Clusters and Central Nodes in the Global Knowledge Economy}

\subsection{An Introduction to Relational Economic Geography}

EG developed as a subdiscipline in geography to analyze spatial aspects in the distribution of economic activity (e.g. Berry et al., 1987; Dicken and Lloyd, 1990, among others). By applying a spatial perspective to economic analyses, EG research sought to provide answers to questions relating to the distribution and location of industrial activities: How can firms' and industries' location decisions be explained? How do spatial disparities result from economic activity? How do market mechanisms contribute to spatial equilibria? Why do some regions grow faster than others? Related research developed a special interest in analyzing and understanding the growth of economic agglomerations. Much of this work was inspired by neoclassical economics, although it became clear that optimization principles are unable to explain the unequal spatial distribution of firms and sustained disequilibria. Parallel to the development of the cluster concept in the management literature by Porter (1990; 1998), EG and innovation researchers understood that, in order to explain spatial economic shifts and economic disparities, it was necessary to analyze industrial firms and their production contexts (e.g. Amin and Robins, 1990; Amin and Thrift, 1992; 
Gertler, 1993) instead of aggregate regional growth. While this trend developed over a longer period, it gave rise to what was later referred to as Relational Economic Geography (Boggs and Rantisi, 2003; Bathelt and Gückler, 2003; 2011; Sunley, 2008).

The relational approach, which developed as one stream in the field of EG, suggests that the analysis of spatial agglomerations of industries requires an investigation of how firms in a region act and interact with one another, how they organize and coorganize production, innovation, and distribution, and how they engage effectively in complex social and spatial divisions of labor within and across spatial boundaries sometimes on a global scale (Faulconbridge, 2006; 2008; Yeung, 2005). In other words, relational geographical approaches focus on agents (the typical unit of analysis is the firm, although other agents are sometimes taken into consideration) and how their practices are affected by and, in turn, affect space.

Relational and knowledge-based explanations of industrial clusters have become attractive because cost-based explanations cannot fully explain clustering processes (Pinch et al., 2003). One relevant contribution is the buzz and pipelines model, which suggests that firms benefit from being located in a cluster not just through costefficient local transactions but also through access to relevant information and knowledge directly related to their industry or technology contexts (Bathelt et al., 2004; Bathelt, 2007). Owing to a concentration of firms producing similar and complementary products, a large variety of information and knowledge exists within such a cluster that can easily be accessed and is constantly updated through planned and unplanned exchanges. This local buzz (Gertler, 1995; Storper and Venables, 2004) feeds into localized learning processes and generates incentives for further agglomeration and the development of specialized labor markets that enable swift knowledge transfers. 
It is clear that clusters of a certain size cannot exist as isolated entities because they require access to external markets to grow and need to develop linkages to knowledge that is not locally available (Owen-Smith and Powell, 2004; Scott, 1998). Accordingly, they need to open up systematically and develop connections with other regional and national economies to keep up with technology and market developments and avoid potentially harmful regional lock-in processes (Grabher, 1992; Uzzi, 1997). The model of local buzz and trans-local (or global) pipelines that developed from these considerations (Bathelt, 2007; Bathelt and Glückler, 2011; Maskell and Malmberg, 2007) picks up on the different types of knowledge flows that develop in such a context and connects internal and external learning dynamics. It suggests that successful clusters need to have a strong ecology of internal and external knowledge linkages in order to direct new knowledge from the outside into the cluster processes and to feed localized learning targeted at the development of new products and processes.

\subsection{Trade Shows in Relational Economic Geography: From Permanent to Temporary}

\section{Clusters}

In this line of thought, trade shows have become a missing link that connects internal cluster processes with external agents and knowledge pools (see Table 1). While much of EG work on clusters in the 1980s and 1990s concentrated on localized synergies and the network effects of regional industry agglomerations, the buzz and pipelines model suggested that cluster success should be viewed as connecting internal and external cycles of knowledge generation and opening network relations geographically. This argument led to questions related to how firms in clusters go about systematically acquiring knowledge about non-local market opportunities and technology developments and how they would establish connections with non-local 
partners. Questions such as these directed EG research to become more interested in the roles of trade shows (Maskell et al., 2006). Similarly to the work of the French proximity school (Boschma, 2005; Rallet and Torre, 1999), trade shows were viewed as events where firms from an organizational field get together, showcase their latest products and technological developments, and have the opportunity to link up with firms from other regions and countries (Norcliffe and Rendace, 2003; Power and Jansen, 2008).

In recognizing that the composition of actors and firms as well as the nature of horizontal and vertical knowledge exchanges resemble those in permanent clusters, major trade shows were viewed as opportunities to acquire first-hand (and face-toface) knowledge about non-local markets and actors. Figure 1 illustrates the idea behind such exchanges. At any given moment, firms in a permanent cluster interact both with other clustered actors through local buzz and with trans-local and international actors through global pipelines (see Figure 1A). Specifically, Figure 1B suggests that cluster firms (as well as non-cluster firms) attend major trade shows in their industry to gain access to new markets, get in contact with customers and suppliers, and acquire relevant information about their industry and technology context. These events resemble miniature versions of global industry clusters with a multitude of firms that are horizontally linked as competitors and vertically related as suppliers or users. During the events, they engage in intensive interaction with all these actors around topics that shape their day-to-day interactions and problemsolving processes, referred to as global buzz (Maskell et al., 2006). Consequently, they develop and maintain networks, find potential future partners, scan other markets, watch their competitors, and use the events as a benchmark to evaluate developments in the industry (Bathelt and Schuldt, 2008; 2010). Based on such interactions and 
knowledge acquisition patterns during trade shows, firms further existing networks and promote trans-local linkages over time. They also approach new markets and extend their spatial reach in consecutive steps (see Figure 1C). Such knowledge eventually flows back into cluster networks (or other industrial contexts) to update and strengthen existing learning structures (Ramirez-Pasillas, 2010).

\section{--- Insert Figure 1 around here ---}

In this line of research, trade shows are conceptualized as temporary clusters (Maskell et al., 2006; Ramirez-Pasillas, 2008) that enable participating firms to engage in intensive interaction based on organized proximity (Torre and Rallet, 2005). Temporary clusters are multidimensional relational spaces where firms can learn through interaction processes with peers, existing or potential value-chain partners, and third parties. Besides their vertical dimension, trade shows offer a unique overview of competition, especially at large international hub events, and they create opportunities for horizontal learning by showing what is going on in the field and which new products competitors are developing. Such feedback generates benchmarks for industrial production and innovation and becomes an important source for firms' decision-making processes. These events also form an important mechanism for technical communities that partly overlap and partly differ to update their knowledge of the organizational field and to discuss technological, market, and political changes. Trade shows thus establish a crucial institutional dimension and provide an effective mechanism to reproduce the related communities and their underlying industries (Bathelt and Schuldt, 2010). 


\section{Industrial Marketing's Impacts on Economic Geography Views Regarding Trade Shows}

While initial EG research brought new dynamics and a broader disciplinary approach to trade show studies, it also had weaknesses that would have been easy to correct for from an IM perspective. First, EG research largely focused on an upstream perspective and investigated the potential feedbacks from trade shows on production and innovation activities, but it widely neglected market-related interactions and their important consequences for knowledge creation and exchange. This research underemphasized the fact that trade shows are in the first place temporary markets that find their raison d'être in the needs of industrial marketers to promote their new products to potential buyers. In fact, these events are mostly 'paid for' by the promotional investments of industrial suppliers (exhibitors) - a fact that has an impact on who can have access to learning and the knowledge that can be exchanged at these events.

Second, initial research tended to investigate individual events as discrete entities and failed to distinguish between different trade show types and their resulting knowledge ecologies. In each industry, there is a multitude of trade shows, each with different timing, marketing function, and target markets - a fact long recognized in the IM literature (Bello and Barczak, 1990; Faria and Dickinson, 1985). IM research investigated such differences to help exhibitors select the trade shows best suited to reach their marketing goals and to address target market segments more costeffectively. In reality, exhibitors and visitors regularly attend various trade shows, following the rhythms of innovation processes and buying time in their respective industries. In most industries, the dates of trade shows are nicely arranged one after another to keep overlaps to a minimum and avoid forcing potential exhibitors and 
visitors to choose between competing events (e.g. Modemonline, 2014). Trade shows serving a given industry are therefore interrelated because some exhibitors and visitors may attend more than one of them (Power and Janssen, 2008), although this is not always the case (Gibson and Bathelt 2014). The interrelatedness of trade shows and the differentiated functions they serve have mostly been neglected in EG research.

Third, EG literature initially paid only limited attention to the roles of trade show organizers (who, in this regard, may be conceived of as temporary cluster organizers). By contrast, the organizers' roles in creating the contextual conditions for exhibitors' promotional activities have been well recognized in the IM literature (Golfetto and Rinallo, 2008; Rinallo and Golfetto, 2006). Specifically, from a knowledge-based perspective, these actors can be considered 'organizers of organized proximity' whose activities can have a significant impact on exhibitors' and visitors' interactions at trade shows. Initial EG scholarship also neglected this point and characterized the knowledge ecologies that these events constitute as spontaneously emerging, without acknowledging that trade show organizers can affect exhibitors' and visitors' learning dynamics.

Over the past few years, attempts have been made to integrate IM insights systematically into EG work on trade shows. This has resulted in more comprehensive conceptualizations of these events. Building on IM scholarship, Rinallo and Golfetto (2011), for instance, suggest that by looking at trade shows as temporary markets, it is possible to gain a better understanding of how trade shows facilitate vertical interaction between exhibitors and 'typical' visitors (Borghini et al., 2006), such as industrial buyers and influencers, whereas other interaction types occur as a sideeffect, when organizers do not actively discourage them. Related work highlights how trade show organizers, particularly when supported by entrepreneurial associations, 
adopt knowledge-based strategies to strengthen the competiveness of their events compared with rival events elsewhere (Rinallo and Golfetto, 2011). This work, adopting a relational perspective, provided new insights into the 'trade show wars' that early geographers observed (Allix, 1922).

In a collaborative effort to integrate IM and EG findings, a recent monograph (Bathelt et al., 2014) systematically examines the roles of trade shows in the globalizing knowledge economy and documents the knowledge-transfer and co-creation practices of visitors, exhibitors, and organizers. This attempt draws on the knowledge-based view of the firm (Maskell, 2001; Nonaka, 1994), which constitutes a 'common language' across the respective disciplinary views and presents empirical evidence of trade show developments in different industries and across various parts of the world (North America, Europe, and Asia) using a joint conceptual lens. This work also identifies the knowledge-based strategies that trade shows organizers use to shape visitors' and exhibitors' interactions and learning processes and to increase show competitiveness in relation to rival events (Bathelt et al., 2014).

An important outcome of this cooperation, which has relevant theoretical and methodological implications for both IM and EG research, is that there are different trade show types that fulfill different purposes and involve different forms of interaction. A fundamental way of distinguishing between trade shows is to compare the levels of international participation on the exhibitor-supplier and visitor-buyer sides with each other (Bathelt et al., 2014; Rinallo and Golfetto, 2011). This leads to a four-fold typology of trade shows consisting of local exchange events, import shows, export shows, and international hub shows (see Figure 2). 
Import shows (with many international suppliers-exhibitors and mainly local buyers as visitors) offer exhibitors the opportunity to learn about local demand (producers, trade channels, customers, etc.), and they provide a better understanding of international competitors and their strategies on the local market. Typically, consumer shows belong in this category. When devoted to professional buyers, these trade shows are initially fairly important in emerging economies - before national manufacturing industries achieve a sufficient level of development (see Li, 2014). Export shows (with many international visitors and mainly local suppliers-exhibitors) offer exhibitors initial contacts with markets abroad and opportunities to learn more about local competitors' international strategies. Such events can, for instance, be found in countries where manufacturing industries are fragmented (e.g. in Italy). $H u b$ shows (characterized by a predominance of foreign exhibitors and visitors) combine many of the elements of the previously mentioned trade show types. They offer many opportunities to learn about global industries, markets, innovations, and marketing practices. They represent an advanced stage of trade show development and usually take place in cities with high international or intercontinental accessibility, in the center of larger manufacturing areas. Many events in the main German trade show cities have such characteristics and have crucial import-export functions in Europe as a whole (Golfetto and Rinallo, 2015; Rinallo and Golfetto, 2011).

In the process of developing a joint knowledge-based conceptualization for the analysis of trade shows, recent EG work has continued to actively engage with and integrate IM insights into investigations of temporary clusters. A number of examples illustrate this: First, Li (2014) adopted Rinallo and Golfetto’s (2011) knowledgebased typology of trade shows to analyze the potential of production-related learning processes at trade shows. By investigating trade shows in the context of developing 
economies in Southeast Asia, he argues that the extreme cases of pure international hub events, local exchange trade shows, and pure import or export shows do not provide the optimal setting for technological learning processes. Instead, a middle ground of events that supply a mix of domestic and international exhibitors and visitors can be crucial to establish the dynamic technological learning spaces for fruitful exchanges between domestic producers and international firms.

Second, going a step further, in a recent collection of research contributions Bathelt and Zeng (2015) conclude from an investigation of the rise and development of trade shows in the Asia-Pacific region that dynamic trade show activities are not just a secondary consequence of globalization processes but can also be viewed as drivers of such developments. Using a political economy approach, this work analyzes different national development trajectories and presents insightful evidence of how active state policies gave rise to dynamic trade show ecologies and how these events shaped economic upgrading processes. Third, recent work has also begun to apply the concept of the temporary cluster to the analysis of business conferences (Henn and Bathelt, 2015) as a next step to investigate other types of temporary business community get-togethers that enable these communities to solve coordination and management problems and reproduce their institutional foundations.

In summary, work in Relational Economic Geography on trade shows initially paid limited attention to the vast IM scholarship that deals with these promotional instruments and found limited use in the firm-based, 'geography-free' theorizations of IM scholarship and their related downstream focus on demand instead of production. It was through contributions that purposely 'translated' key concepts from IM into EG that IM scholarship began to have an impact on EG understandings of trade shows. Knowledge flows in the opposite direction have been less pronounced, and the 
question remains how an EG perspective could impact or enrich IM studies into these events.

\section{Potential Contributions of Economic Geography Perspectives to Industrial}

\section{Marketing Research on Trade Shows}

Based on our analysis, we suggest that EG views can help IM scholars in numerous ways to develop better conceptualizations of how trade shows and similar event types shape learning and knowledge co-creation, innovation, and, more generally, the marketing of firms and places. This knowledge-based perspective can contribute to several ongoing conversations in the IM literature (see Table 2 for an overview).

\subsection{Contributions to Research on Learning and Resource Interaction at Trade Shows}

In the IM field, trade shows are mainly seen as promotional instruments. The important role of these events in the circulation, exchange, and generation of knowledge has long been downplayed and understudied. IM scholarship only recently began to unpack the market-related learning processes at these events (Borghini et al., 2006; Golfetto, 2004; Li, 2006; 2007; Rinallo et al., 2010; Zerbini and Borghini, 2012; Zerbini et al., 2006). To go deeper into this point, a brief introduction to the ways in which EG and IM conceptualize knowledge is necessary. Here, we focus on work in the Industrial Marketing and Purchasing (IMP) research tradition (Ford, 1980; Ford et al., 1998; Håkansson, 1992; Håkansson et al., 2009), which has long investigated how learning and innovation processes take place across organizational and spatial boundaries. Therefore, it can engage more fruitfully with EG literature to produce a better understanding of trade shows as contexts for interaction, networking, and relationship building. 
Building on the idea that tacit knowledge is sticky and difficult to transfer across locations (Polanyi, 1966; Szulanski, 2000; Von Hippel, 1994), IMP literature highlights that innovation typically originates in the context of business relationships (La Rocca and Snehota, 2014; Håkansson and Waluszewski, 2007). At the core of knowledge creation and innovation processes is the mutual deployment of resources that are successfully combined over extended interaction episodes (Baraldi and Waluszewski, 2005; Baraldi et al., 2012; Gadde et al., 2012; La Rocca and Snehota, 2014). From this perspective, the temporary nature of trade shows would not permit the type of extended interaction opportunities that business relationships enable. Even worse, according to most IMP theory, it is impossible to disentangle knowledge from the structures in which it is created (e.g., Eklund and Waluszewki, 2015), making it impossible for the knowledge that can circulate or spill over at trade show to be valuable. $^{1}$

Unlike other perspectives that link economics and geography, ${ }^{2}$ Relational Economic Geography has long investigated the problematic nature of knowledge transfer across distance and organizational divides. In his review of related literature, Maskell (2014),

${ }^{1}$ We are grateful to an anonymous reviewer for highlighting these important issues.

${ }^{2}$ We refer in particular to Krugman's (1998) geographical economics, which - like other EG approaches - looks at how economic activity clusters and agglomerates in space. As a whole, geographical economics conceives of knowledge externalities in clusters as (relatively easy-to-access) information spillovers (see Döring and Schnellenbach, 2006, for a discussion of different typologies of knowledge spillovers). Such work, which has played an important role in introducing geographical notions to the field of economics, has been criticized for using a rather narrow perspective to analyze EG problems (e.g. Martin and Sunley, 1996). In short, like most fields, EG is characterized by a diversity of perspectives that do not all resonate well with the knowledge generation and learning perspective developed in IMP theory. 
for instance, highlights that a firm needs to identify sources of remote knowledge in relation to their specific needs before the transfer of remote knowledge can occur. When adopting this conceptual lens, the business relationships that form the central units of analysis in the IMP approach are the most appropriate sources of remote knowledge when a firm has high awareness of both the specific knowledge it needs and a suitable source that can provide or help co-produce such knowledge. By contrast, when firms lack a clear understanding of the kinds of knowledge that might be helpful or which source might best provide such knowledge, trade shows can play a fundamental role in providing an overview of new ideas and alternative potential business partners (Borghini et al., 2006; Maskell, 2014; Rinallo et al., 2010).

While interaction episodes at trade shows might play an important role in the initial stages of the business relationship lifecycle, their cyclic nature means that they provide repeated occasions for resource interaction in the context of existing relationships. A useful model to classify and analyze resource interaction in interorganizational networks is the 4R model (Håkansson and Waluszewski, 2002), which describes how four types of resources (products, facilities, organizational units, and inter-organizational relationships) interact with each other. While a full theoretical exploration of trade shows as platforms for ongoing resource interaction is beyond the goal of this paper, some general considerations are advanced in Table 3. Extant research, building on IMP scholarship, has already started exploring interaction at trade shows (Evers and Knight, 2008; Rice, 1992; Rosson and Seringhaus, 1995; Sarmento et al., 2015). The ideas advanced in this paper could strengthen this body of work and result in a more thorough understanding of the intra- and interorganizational learning and resource interaction processes that these events facilitate. 
Research on trade shows also provides a theoretical opportunity to better conceptualize space. The geographical localization of a firm has mostly been viewed as a hindrance to its operation in IM research (Håkansson et al., 2006). In the IMP research tradition, early contributions (Håkansson, 1982) equated space with distance, seen as an obstacle to social interaction between actors. More recent contributions, building on the industrial cluster literature, suggest that place can be a source of competitive advantage for individual firms and that it can be understood as a combination of resources that can be strategically combined with resources from other places to produce a competitive advantage across space (Håkansson et al., 2006).

Work in relational EG (for a review, see Bathelt et al., 2014) demonstrates that firms exhibiting at trade shows obtain crucial experiential knowledge about how to adapt their core productive competencies to the heterogeneous needs of customers in different industries and geographical markets thanks to deliberate and emerging interactions with numerous actors. Most firms have a trade show portfolio comprising multiple participations across a number of industries and geographical markets, which increases the number of opportunities for learning and resource interaction/combination previously described (see again Table 3). Future IM scholarship on learning at trade shows would benefit from the adoption of a geographic lens (Bathelt and Glückler, 2011) in their conceptualization of the processes through which trade shows in different parts of the world enable industrial marketers to tap into specific bases of market knowledge, observe the behavior of the competitors that serve these markets, and ultimately develop innovations that are suited to a variety of foreign needs and preferences. By better contextualizing the geography of learning, IM scholars may be able to have a more thorough understanding of the roles of trade shows in the internationalization of industrial firms, 
the development of complementary assets (Rothaermel, 2001a; 2001b; Teece, 1986) necessary to successfully commercialize and promote innovations, and, ultimately, the evolving focus of these players from a product to a market orientation (Kohli and Jaworski, 1990; Narver and Slater, 1990).

\subsection{Contributions to Research on Exhibitors' Performances}

Empirical generalizations of exhibitors' performances constitute the bulk of IM research on trade shows. There are several ways in which Relational Economic Geography perspectives can enrich attempts to measure and identify determinants of trade show performances.

First, research on trade shows is mostly focused on exhibitors and their interactions with visitors. Trade show organizers are still understudied from an IM perspective, even though these organizations can significantly impact interaction and learning at these events (Bathelt et al., 2014; Rinallo and Golfetto, 2011, 2015, 2017) and, more importantly from an IM perspective, the effectiveness of exhibitors' promotional strategies. Such a perspective highlights how exhibitors and organizers are often in conflict with one another for various reasons that can range from stand location in the exhibition venue to changes in trade show strategy (e.g. date, hosting city or venue, admission of foreign exhibitors, etc.). To date, IM research has only hinted at how trade show organizers can affect individual exhibitors' value-creation and profit maximization (Borghini et al., 2006; Geigenmüller and Bettis-Outland, 2012; Golfetto and Rinallo, 2008; Gopalakrishna et al., 2010; Munuera and Ruiz, 1999; Rinallo and Golfetto, 2006; Rinallo et al., 2006, 2012). More research is needed to investigate organizer-visitor and organizer-exhibitor interactions and relationships, and to unpack 
the impact of organizers' competencies and activities on exhibitors' return on investment.

Second, the IM literature on visitor behavior at trade shows mostly sees these events as information sources used by industrial buyers in their purchasing processes (for a review and critique, see Borghini et al., 2006). A core concept of IM research is the buying center (Jackson et al., 1984; Johnston and Bonoma, 1981; Kohli, 1989; Lilien and Wong, 1984). A limited number of IM studies highlighted that buying center members belong to different occupational communities (Andersen, 2005; Araujo, 2004; Cayla et al., 2013; Rinallo et al., 2007, 2008). Work in EG demonstrates that trade shows provide a meeting ground for different occupational communities (Bathelt et al., 2014; Bathelt and Schuldt, 2010) that are connected to the organizational field in different ways. Related studies characterize these groups as epistemic communities (Bathelt et al., 2014; Cohendet et al., 2014) that engage in collective practices of sensemaking and knowledge creation. Marketing literature has already examined the practices through which communities of consumers collectively create value and the ways in which consumer brands can encourage and benefit from these practices (Schau et al., 2009). Taking inspiration from corresponding work in EG and consumer marketing, the IM literature could systematically investigate the influence of networks within and across occupational communities and their impact on firms' buying and innovation processes.

Third, in terms of methodology, IM research on trade shows has paid limited attention to the fact that trade shows in different industries and different parts of the world are remarkably different from each other (Bathelt et al., 2014). Rinallo and Golfetto's (2011) typology of trade shows (see Figure 2) provides a first attempt at examining how trade show characteristics affect the specific knowledge circulation practices at 
given events. This taxonomy can also be used to inform trade shows' theoretical sampling (Glaser and Strauss 1967; Yin 1994) in empirical research. Similarly, IM research should pay more attention to context - a crucial analytical category in Relational Economic Geography - as predictors of trade show performance might be contingent on the type of trade show examined and the geographic context in which an event is situated. For example, the performances obtained in a hub trade show in Germany might differ radically from those in an import-oriented trade show in China. Treating trade shows as if they were similarly structured events makes it difficult to interpret empirical evidence accurately and to generalize findings across industries and events. Therefore, IM researchers should try to avoid essentializing trade shows as if they were homogenous events irrespective of location and industry.

We conclude by noting that most IM research on trade shows is carried out in a North American or European context, where the trade show business is mature (Bathelt et al., 2014). Asia, and to a lesser extent South America and Eastern Europe, are characterized by smaller but high-growth trade show markets (CERMES, 2014). By disregarding geography, IM trade show literature downplays the effects of globalization forces on these events. An EG perspective helps to provide a contextual understanding of how macro-level factors affecting global supply chains are driving the trade show industry's evolution. Unsurprisingly, EG is presently devoting more attention to trade shows in Asia and other non-Western countries (Bathelt and Zheng, 2015; Golfetto and Rinallo, 2015; Li, 2014; Vendrusculo, 2016). IM work in these emerging trade show countries is not the center of attention. Future research on trade show performance should help exhibitors - whether local industrial marketers or foreign firms seeking to enter these markets - make the most of their investments in these contexts, too. 


\subsection{Contributions to Research on Trade Shows as Collective Marketing Tools}

Finally, EG perspectives on trade shows can also inspire IM scholars to explore the relevance of these events from a collective marketing perspective (Rinallo and Golfetto, 2006), which to date has attracted only limited attention. Here, we discuss promising areas for future research: First, industry associations and other industry actors sometimes use trade shows as collective promotional platforms. This happens frequently in the case of export-oriented shows, which trade associations tend to organize or strongly support. Bathelt et al. (2014) report a number of empirical cases showing how Italian trade shows in different industries have helped local manufacturers, through the mediation of trade associations, to promote their competencies and create a collective nation brand (see literature on country-of-origin effects, e.g. Al-Sulaiti and Baker, 1998; Dinnie, 2004; Peterson and Jolibert, 1995; Verlegh and Steenkamp, 1999). Building on anthropological theory on trade fairs (Peñaloza, 2000; 2001), Bathelt et al. (2014) highlight these events' culture-producing functions and their roles in presenting the historical roots of local/national industries to international markets and educating industrial buyers and other market actors about the functional and symbolic qualities of locally manufactured products. More research is needed regarding this collective level of marketing (Felzensztein et al., 2013; Nicholson et al., 2013). By creating a positive nation brand and by attracting foreign buyers, trade shows may be especially beneficial to the survival and growth of smaller industrial firms.

Second, work in EG highlights the fact that trade shows can affect the innovation trajectories of their underlying industries. For instance, Rinallo and Golfetto (2011) found that trade show organizers in clothing textiles invest in market research about emerging fashion trends that is mostly disseminated to small and medium-sized 
exhibitors, which incorporate the results of such research (e.g. in terms of colors, patterns, or raw materials) into their new products. Similarly, Bathelt et al. (2014) found that Italy's Salone del Mobile furniture show attracted the attention of international media and retailers by providing visibility to collaborations between furniture makers and designers. The commercial benefits resulting from such esposure stimulated other Italian furniture manufacturers to invest in developing their design capabilities. IM research could benefit from macro-level longitudinal examinations of trade shows and their broader impacts on the patterns of innovation of local and national industries.

Third, given the recent emphasis on industrial clusters and networks in IM research (Cantù, 2010; Corsaro et al., 2012; Eklinder-Frick et al. 2011; 2012), an EG perspective draws attention to the links between localized industries and trade shows (see Figure 1). Work in EG highlights that some trade shows tend to restrict access to non-local exhibitors as the organizers, controlled by local industry associations, adopt a protectionist attitude (Rinallo and Golfetto, 2011). From a knowledge-based perspective, such approaches result in limited exhibitor learning at these events, which is related to a lack of opportunities to observe non-local competitors. Phrased differently, some trade shows may reproduce the institutional lock-in problem of permanent clusters (Boschma, 2005), which is found in geographical areas where embedded economic actors are at risk of becoming self-referential and less open to external stimuli for change. IM research on industrial networks should therefore critically examine the relationships between geographically embedded clusters and trade shows, which may prove dysfunctional and eventually become an obstacle to firm internationalization. 
Fourth, an EG perspective draws attention to (often publicly subsidized) collective participations at trade shows, which are considered necessary during the early stages of firms' internationalization process, when they lack the organizational skills and financial resources to attend foreign trade shows (Seringhaus and Rosson, 1998; Skallerud, 2010). Research on this end has shown that 'collective stands' underperform compared with individual stands (Seringhaus and Rosson, 1998; Skallerud, 2010) - the managerial implication of such findings is that industrial marketers, as soon as they can afford it, should give up collective participations in favor of individual stands. A knowledge-based perspective can revolutionize the logic behind these export promotion initiatives. It can shift from being based on renting larger exhibition areas that are split between local exhibitors (collective stand logic) to designing persuasive experiences for visitors by means of appropriate contents and stand designs, the selection of specific exhibitors (especially market leaders), and the organization of leisure and cultural events. Such strategic concept design would seek to create a specific image for the region, its producers, and their competencies. Some actors (including export promotion state agencies and trade show organizers) have already started working in this direction and paved the way for IM researchers to empirically explore the conditions under which these initiatives can create value for such little-understood temporary networks.

Finally, work in EG emphasizes the global spatial perspective that ultimately affects industrial buyers' behavior, industrial marketers' promotional strategies, trade shows' competitiveness, and the evolving territorial distribution of the global trade show industry. The roles of trade shows in the context of individual and collective marketing strategies cannot be analyzed independently from global trends in their underlying industries, which affect the lifecycles of specific events and the evolution 
of continental trade show platforms (Bathelt et al, 2014; Golfetto and Rinallo, 2015). Both exhibitors' evolving trade show portfolios and trade show lifecycles are affected by macroeconomic dynamics. By becoming more aware of geographic context, IM scholarship on trade shows may be able to provide better guidance to trade show organizers and, ultimately, the actors using these events as marketing tools: exhibitors and industry associations, as well as export promotion authorities, policy markers, and local governments.

\section{Conclusion}

This paper critically reviews literature on trade shows developed in the fields of Industrial Marketing (IM) and Economic Geography (EG). In IM, trade shows are conceived as promotional instruments through which firms operating in industrial markets strengthen their brands and build and maintain relationships with current and potential buyers. In EG, trade shows are seen as temporary clusters through which firms can escape the liabilities of embeddedness and interact with (and learn from) distant actors. Our analysis shows that IM scholarship has provided a means for EG literature to go beyond earlier formulations, which did not pay enough attention to the fact that trade shows are temporary markets sustained by exhibitors' promotional investments. By integrating insights from IM, EG literature has generated more comprehensive conceptualizations of trade shows that acknowledge the predominance of vertical relationships between industrial suppliers and purchasers, as well as the knowledge-based strategies organizers can adopt to make their events knowledge-rich places for exhibitors and visitors. We also noted that IM scholarship, while recently highlighting learning as a key dimension of exhibitors' trade show performance, can be criticized for undertheorizing space and not engaging with EG literature on these 
events and their role in the global knowledge economy. Building on these premises, we suggest that EG literature could enrich IM trade show scholarship about learning and resource interaction at trade shows, exhibitor performance, and trade shows as collective marketing instruments (see Table 2).

We conclude with some remarks on the benefits and challenges of transdisciplinary research, based on our own experience of boundary spanning and co-authorship across IM and EG, during which our understanding of trade shows was enriched beyond our expectations. From this experience, we realize that transdisciplinary research has a number of important advantages, including exposure to different research questions, literatures, and methodologies. As a result, it is possible to critically examine seemingly established and rarely questioned views within a field and develop a more thorough understanding of the empirical phenomenon under investigation. Transdisciplinary endeavors along these lines have undeniable merits, but we must confess that some aspects could easily get 'lost in translation,' and parent discipline observers might consider the resulting work to be superficial. Transdisciplinary research - beyond the superficial appropriation of key ideas - is notoriously difficult and threatened by numerous pitfalls. Disciplinary language and underlying theoretical perspectives may lead to divergent interpretations of the same empirical phenomena. For example, an EG researcher observing an import-oriented trade show in Asia may see limited opportunities for learning and knowledge exchanges, whereas an IM scholar may see many opportunities. Why? The former may focus on reduced technological knowledge exchanges, while the latter may point at learning opportunities related to market interactions.

Additionally, the publication of truly transdisciplinary research does not go unchallenged. Expectations in terms of methodological rigor, construction of 
theoretical arguments, and practical implications vary remarkably, and journal editors and reviewers are not always knowledgeable about, or tolerant of, approaches that are not part of the mainstream in their home discipline. For transdisciplinary research to be published, academic gatekeepers must be willing not only to accept the 'otherness' of approaches and perspectives from cognate disciplines but also to engage actively with these differences and recognize their potential for reciprocal enrichment. It takes time and a great degree of acceptance to develop a shared understanding and a common vocabulary across disciplines. Extended face-to-face interactions, seminars, joint workshops, special sessions at conferences, special issues of academic journals, and edited books may therefore be crucial to develop shared research repertoires (from language to methodology) and engage in collective sensemaking.

\section{Acknowledgements}

We would like to thank the editors and reviewers of Industrial Marketing Management for their helpful suggestions and stimulating discussions that helped sharpen our arguments, to which all authors the contributed in equal measure.

\section{References}

Al-Sulaiti K.I., Baker M.J. (1998). Country of origin effects: A literature review. Marketing Intelligence \& Planning 16 (3): 150-99.

Allix A. (1922). The geography of fairs: Illustrated by old-world examples. Geographical Review 12: 532-69.

Amin A., Robins K., (1990). The re-emergence of regional economics? The mythical geography of flexible accumulation. Environment and Planning D 8: 7-34.

Amin A., Thrift N. (1992). Neo-Marshallian nodes in global networks. International Journal of Urban and Regional Research 16: 571-87.

Andersen P.H. (2005). Relationship marketing and brand involvement of professionals through web-enhanced brand communities: The case of Coloplast. 
Industrial Marketing Management 34 (1): 39-51.

Araujo L. (2004). Technological practice, firms, communities and networks. Working paper. The Department of Marketing, Lancaster University.

Banting P.M., Blenkhorn D.L. (1974). The role of industrial trade shows. Industrial Marketing Management 3 (5): 285-95.

Baraldi E., Waluszewski A. (2005). Information technology at IKEA: an 'open sesame' solution or just another type of facility? Journal of Business Research 58 (9): 1251-60.

Baraldi E., Gressetvold E., Harrison D. (2012). Resource interaction in interorganizational networks: Foundations, comparison, and a research agenda. Journal of Business Research 65 (2): 266-76.

Bathelt H. (2007). Buzz-and-pipeline dynamics: Toward a knowledge-based multiplier model of clusters. Geography Compass 1: 1282-98.

Bathelt H., Golfetto F., Rinallo D. (2014). Trade Shows in the Globalizing Knowledge Economy. Oxford: Oxford University Press.

Bathelt H., Glückler J. (2003). Toward a relational economic geography. Journal of Economic Geography 3: 117-44.

Bathelt H., Glückler J. (2011). The Relational Economy. Geographies of Knowing and Learning. Oxford: Oxford University Press.

Bathelt H., Malmberg A., Maskell P. (2004). Clusters and knowledge: Local buzz, global pipelines and the process of knowledge creation. Progress in Human Geography 28: 31-56.

Bathelt H., Schuldt N. (2008). Between luminaries and meat grinders: International trade fairs as temporary clusters, Regional Studies 42: 853-68.

Bathelt H., Schuldt N. (2010). International trade fairs and global buzz, part I: Ecology of global buzz. European Planning Studies 18: 1957-74.

Bathelt H., Taylor M. (2002). Clusters, power and place: Inequality and local growth in time-space. Geografiska Annaler 84B: 93-109.

Bathelt H., Zeng G. (eds) (2015) Temporary Knowledge Ecologies: The Rise of Trade Fairs in the Asia-Pacific Region. Cheltenham, Northampton, MA: Edward Elgar.

Bellizzi J.A., Lipps D.J. (1984). Managerial guidelines for trade show effectiveness, Industrial Marketing Management 13 (1): 49-52.

Bello D.C. (1992). Industrial buyer behavior at trade shows: Implications for selling effectiveness. Journal of Business Research 25 (1): 59-80.

Bello D.C., Barczak G.J. (1990). Using industrial trade shows to improve new product development. Journal of Business \& Industrial Marketing 5: 43-56.

Bello D.C., Lohtia R. (1993). Improving trade show effectiveness by analyzing attendees. Industrial Marketing Management 22 (4): 311-8. 
Berry B.J.L., Conkling E.C., Ray D.M (1987). Economic Geography: Resource Use, Locational Choices, and Regional Specialization in the Global Economy. Englewood Cliffs, NJ: Prentice-Hall.

Bettis-Outland H., Cromartie J.S., Johnston W.J., Borders A.L. (2010). The return on trade show information (RTSI): A conceptual analysis. Journal of Business \& Industrial Marketing 25 (4): 268-71.

Bettis-Outland H., Johnston W.J., Wilson R.D. (2012). Using trade show information to enhance company success: An empirical investigation. Journal of Business \& Industrial Marketing 27 (5): 384-91.

Black R. (1986). The Trade Show Industry: Management and Marketing Career Opportunities. East Orleans, MA; Trade Show Bureau.

Blythe J. (2002). Using trade fairs in key account management. Industrial Marketing Management 31: 627-35.

Boggs J.S., Rantisi N.M. (2003). The 'relational turn' in economic geography. Journal of Economic Geography 3: 109-16.

Bonoma T.V. (1983). Get more out of your trade shows. Harvard Business Review 61 (January-February): 75-83.

Borghini S., Golfetto F., Rinallo D. (2006). Ongoing search among industrial buyers. Journal of Business Research 59: 1151-9.

Boschma R.A. (2005). Proximity and innovation: A critical assessment. Regional Studies 39: 61-74.

Cantù C. (2010). Exploring the role of spatial relationships to transform knowledge in a business idea -- Beyond a geographic proximity. Industrial Marketing Management, 39(6), 887-897.

Carman J.M. (1968). Evaluation of trade show exhibitions. California Management Review 11 (2): 35-44.

Cavanaugh S. (1976). Setting objectives and evaluating the effectiveness of trade show exhibits. Journal of Marketing 40 (October): 100-3.

Cayla J., Cova B., Maltese L. (2013). Party time: Recreational rituals in the world of B2B. Journal of Marketing Management 29 (11-12): 1394-421.

CERMES (2014). Annual Report on the Trade Fair Sector in Europe. Milan (Italy): Bocconi University.

Cohendet P., Grandadam D., Simon L., Capdevila I. (2014). Epistemic communities, localization, and the dynamic of knowledge creation. Journal of Economic Geography 14 (5): 929-54.

Corsaro D., Cantù C., Tunisini A. (2012). Actors' heterogeneity in innovation networks. Industrial Marketing Management 41 (5): 780-9.

Deeter-Schmelz D.R., Kennedy K.N. (2002). An exploratory study of the Internet as an industrial communication tool. Examining buyers' perceptions. Industrial Marketing Management 31: 145-54. 
Dekimpe M.G., François P., Gopalakrishna S., Lilien G.L., Van den Bulte C. (1997). Generalizing about trade show effectiveness: A cross-national study. Journal of Marketing 61 (October): 55-64.

Dicken P., Lloyd P.E. (1990). Location in Space. Theoretical Perspectives in Economic Geography. 3rd edn., New York: Harper Collins

Dinnie K. (2004). Country-of-origin 1965-2004: A literature review. Journal of Customer Behaviour 3 (2): 165-213.

Eklinder-Frick J., Eriksson L.-T., Hallén L. (2011). Bridging and bonding forms of social capital in a regional strategic network. Industrial Marketing Management 40 (6): 994-1003.

Eklinder-Frick J., Eriksson L.-T., Hallén L. (2012). Effects of social capital on processes in a regional strategic network. Industrial Marketing Management 41 (5): 800-806.

Eklund M., Waluszewski A. (2015). The diversity of systemic innovations thinking: The theoretical underpinnings of NIS and IMP and the different assessment of an industry, IMP Journal 9 (1): 26-45.

Evers N., Knight J. (2008). Role of international trade shows in small firm internationalization: A network perspective, International Marketing Review 25 (5): 544-62.

Faria A.J., Dickinson J.R. (1985). What kind of companies use trade shows most and why. Business Marketing 71: 150-55.

Faulconbridge J. (2006). Stretching tacit knowledge beyond a local fix? Global spaces of learning in advertising professional service firms. Journal of Economic Geography 6: 517-40.

Faulconbridge J. (2008). Managing the transnational law firm: A relational analysis of professional systems, embedded actors, and time-space-sensitive governance. Economic Geography 84: 185-210.

Felzensztein C., Stringer C., Benson-Rea M., Freeman S. (2014). International marketing strategies in industrial clusters: insights from the southern hemisphere. Journal of Business Research 67 (5): 837-46.

Florio M. (1994). Fair Trades by trade fairs: Information providing institutions under monopolistic competition. Small Business Economics 6: 267-81.

Ford D. (1980). The development of buyer-seller relationships in industrial markets. European Journal of Marketing 14 (5/6): 339-53.

Ford D., Gadde L.-E, Håkansson H., Lundgren A., Snehota I., Turnbull P., Wilson D. (1998). Managing business relationships. Chichester: Wiley.

Gadde L.-E., Hjelmgrem D., Skarp F. (2012). Interactive resource development in new business relationships. Journal of Business Research 65 (2): 210-17.

Geigenmüller A., Bettis-Outland H. (2012). Brand equity in B2B services and consequences for the trade show industry. Journal of Business \& Industrial 
Marketing 27 (6): 428-35.

Gibson R., Bathelt H. (2014). Field configuration or field reproduction? The dynamics of global trade fair cycles. Zeitschrift für Wirtschaftsgeographie 58 (4): 216-31.

Glaser B.G., Strauss A.L. (1967). The Discovery of Grounded Theory: Strategies for Qualitative Research. Chicago: Aldine.

Godar S.H., O’Connor O.J. (2001). "Same time next year" - Buyer trade show motives. Industrial Marketing Management 30 (1): 77-86.

Golfetto F. (2004). Fiere e Comunicazione: Strumenti per le Imprese e il Territorio [Trade Fairs and Communication: Instruments for businesses and territories]. Milan, EGEA.

Golfetto F., Gibbert, M. (2006). Marketing competencies and the sources of customer value in business markets, Industrial Marketing Management 35 (8): 904-12.

Golfetto F., Rinallo D. (2008). Reshaping market through collective marketing strategies: Lesson from the textile industry. In Tollin K. and Carù A. (eds.) Strategic Market Creation: A New Perspective on Marketing and Innovation Management, Chichester: John Wiley \& Sons.

Golfetto F., Rinallo D. (2012). Trade Shows events: from live to digital, in C. Peraboni (ed.), Exhibition in Years2.0: between internationalization and local development, Milan: Egea.

Golfetto F., Rinallo D. (2015). The evolution of trade show systems: Lessons from Europe. In H. Bathelt and G. Zeng (eds.) Temporary Knowledge Ecologies: The Rise and Evolution of Trade Fairs in Asia-Pacific, Edward Elgar, 42-66.

Gopalakrishna S., Lilien G. (1995). "A Three-Stage Model of Industrial Trade Show Performance”, Marketing Science 14 (1), 22-42.

Gopalakrisna S., Lilien G.L., Williams J.D., Sequeira I.K. (1995). Do trade shows pay off? Journal of Marketing 59 (3): 75-83.

Gopalakrishna S., Roster C.A., Sridhar S. (2010). An exploratory study of attendee activities at a business trade show. Journal of Business \& Industrial Marketing 25 (4): 241-8.

Gopalakrishna S., Williams J.D. (1992). Planning and performance assessment of industrial trade shows: An exploratory study. International Journal of Research in Marketing 9 (3): 207-24.

Gertler M.S. (1993). Implementing advanced manufacturing technologies in mature industrial regions: Towards a social model of technology production. Regional Studies 27: 665-80.

Gertler M.S. (1995). 'Being there': Proximity, organization, and culture in the development and adoption of advanced manufacturing technologies. Economic Geography 71: 1-26.

Grabher G. (1993). Rediscovering the social in the economies of interfirm relations. 
In Grabher G (ed) The Embedded Firm. On the Socioeconomics of Industrial Networks. London, New York: Routledge, 1-31.

Hansen K. (1996). The dual motives of participants at international trade fairs. International Marketing Review 13 (2): 39-53.

Hansen K. (2004). Measuring performance at trade shows: Scale development and validation. Journal of Business Research 57 (1): 1-13.

Håkansson H. (1982). International Marketing and Purchasing of Industrial Goods: An Interaction Approach. Chichester: Wiley.

Håkansson H., Ford D., Gadde L.-E., Snehota I., Waluszewski A. (2009) Business in Networks. Chichester: Wiley.

Håkansson H., Tunisini A., Waluszewski A. (2006). Place as resource in business networks. In: Baraldi E., Fors H., Houltz A. (eds). Taking Place: The Spatial Contexts of science, technology and business. Science History Publications, Sagamore Beach, USA.

Håkansson H., Waluszewski A. (2002). Path dependence: Restricting or facilitating technical development? Journal of Business Research 55: 561-70.

Håkansson H., Waluszewski A. (eds) (2007). Knowledge and Innovation in Business and Industry. The Importance of Using Others. London, New York: Routledge.

Henn S., Bathelt H. (2015). Knowledge generation and field reproduction in temporary clusters and the role of business conferences. Geoforum 58: 104-13.

Herbig P., O'Hara B., Palumbo F. (1993). Measuring trade show effectiveness: An effective exercise? Industrial Marketing Management 23: 165-70.

Jackson D.W., Keith J.E., Burdick R.K. (1984). Purchasing agents' perceptions of industrial buying center influence: A situational approach. Journal of Marketing 48 (4): 75-83.

Johnston W.J., Bonoma T.V. (1981). The buying center: Structure and interaction patterns. Journal of Marketing 45 (3): 143-56.

Kerin R.A., Cron W.L. (1987). Assessing trade show functions and performance: An exploratory study. Journal of Marketing 51 (3): 87-94.

Kohli A. (1989). Determinants of influence in organizational buying: A contingency approach. Journal of Marketing 53 (3): 50-65.

Kohli A.K., Jaworksi B.J. (1990). Market orientation: The construct, research propositions, and managerial implications. Journal of Marketing 54 (2): 1-18.

La Rocca A., Snehota I. (2014). Relating in business networks: Innovation in practice. Industrial Marketing Management 43 (3): 441-7.

Li P.-F. (2014). Global temporary networks of clusters: Structures and dynamics of trade fairs in Asian economies. Journal of Economic Geography 14: 995-1021.

Lilien G.L.,Wong M.A. (1984). An exploratory investigation of the structure of the buying center in the metalworking industry. Journal of Marketing Research 21 
(1): $1-11$.

Ling-yee L. (2006). Relationship learning at trade shows: Its antecedents and consequences. Industrial Marketing Management 35 (2): 166-77.

Ling-yee L. (2007). Marketing resources and performance of exhibitor firms in trade shows: A contingent resource perspective. Industrial Marketing Management 36 (3): 360-70.

Ling-yee L. (2008). The effects of firm resources on trade show performance: How do trade show marketing processes matter? Journal of Business \& Industrial Marketing 23 (1): 35-47.

Martin R., Sunley P. (1996). Paul Krugman's geographical economics and its implications for regional development theory: A critical assessment. Economic Geography 72 (3): 259-92.

Maskell P. (2001). The firm in economic geography. Economic Geography 77: 32944.

Maskell P. (2014). Accessing remote knowledge - The roles of trade fairs, pipelines, crowdsourcing and listening posts. Journal of Economic Geography 14: 883902.

Maskell P., Bathelt H., Malmberg A. (2006). Building global knowledge pipelines: The role of temporary clusters. European Planning Studies 14: 997-1013.

Maskell P., Malmberg A. (2007). Myopia, knowledge development and cluster evolution. Journal of Economic Geography 7: 603-18.

Modemonline (2014). Trade Show Calendar. Modemonline. Available online: <http://www.modemonline.com/fashion/tradeshows-calendar/by-date/01-2016>, accessed 2 January 2016.

Moriarty R.T., Spekman R.E. (1984). An empirical investigation on the information sources used during the industrial buying process. Journal of Marketing Research 21: 137-47.

Lilien G.L. (1993). A descriptive model of the trade show budgeting decision process. Industrial Marketing Management 12: 25-9.

Munuera J.L., Ruiz S. (1999). Trade fairs as services: A look at visitors' objectives in Spain. Journal of Business Research 44 (1): 17-24.

Narver J.C., Slater S.F. (1990). The effect of a market orientation on business profitability. Journal of Marketing 54: 20-35.

Nicholson J.D., Tsagdis D., Brennan R. (2013). The structuration of relational space: Implications for firm and regional competitiveness. Industrial Marketing Management 42 (3): 372-81.

Nonaka I. (1994). A dynamic theory of organizational knowledge creation. Organization Science 5: 14-37.

Norcliffe G., Rendace, O. (2003). New geographies of comic book production in North America: The new artisans, distancing, and the periodic social economy. 
Economic Geography 79: 241-73.

Owen-Smith J., Powell W.W. (2004). Knowledge networks as channels and conduits: The effects of spillovers in the Boston biotechnology community. Organization Science 15: 5-21.

O’Hara B., Palumbo F., Herbig P. (1993). Industrial trade shows abroad. Industrial Marketing Management 22 (3): 233-7.

Parasuraman A. (1981). The relative importance of industrial promotion tools. Industrial Marketing Management 10: 277-81.

Peñaloza L. (2000). The commodification of the American West: Marketers' production of cultural meanings at the trade show'. Journal of Marketing 64 (4): 82-109.

Peñaloza L. (2001). Consuming the American West: Animating cultural meaning and memory at a stock show and rodeo. Journal of Consumer Research 28 (December): 369-98.

Peterson R.A., Jolibert A.J.P. (1995). A meta-analysis of country-of-origin effects. Journal of International Business Studies 26 (4): 883-900.

Pinch S., Henry N., Jenkins M., Tallmann S. (2003). From 'industrial districts' to 'knowledge clusters': A model of knowledge dissemination and competitive advantage in industrial agglomerations. Journal of Economic Geography 3: 373-88.

Polanyi M. (1966). The Tacit Dimension. Garden City, NJ: Doubleday Anchor.

Porter M.E. (1990). The Competitive Advantage of Nations. New York: Free Press.

Porter M.E. (1998). Clusters and the new economics of competition. Harvard Business Review 77-90.

Power D., Jansson J. (2008). Cyclical clusters in global circuits: Overlapping spaces in furniture trade fairs. Economic Geography 84: 423-48.

Rallet A., Torre A. (1999). Is geographical proximity necessary in the innovation networks in the era of global economy? Geojournal 49: 373-80.

Ramírez-Pasillas, M. (2008). Resituating proximity and knowledge cross-fertilization in clusters by means of international trade fairs. European Planning Studies 16: 643-63.

Ramírez-Pasillas, M. (2010). International trade fairs as amplifiers of permanent and temporary proximities in clusters. Entrepreneurship and Regional Development 22: $155-87$.

Rice, G. (1992) Using the interaction approach to understand international trade shows. International Marketing Review 9 (4): 32-45.

Rinallo D., Borghini S., Golfetto F. (2010). Exploring visitor experiences at trade shows. Journal of Business \& Industrial Marketing 25 (4): 249-58.

Rinallo D., Borghini S., Golfetto F. (2012). The influence of occupational 
communities on buying behavior, in Borghini et al. (eds.) Prodotto, Consumatore e Politiche di mercato, quarant'anni dopo. Milan: Egea Online.

Rinallo D., Golfetto F. (2006). Representing markets: The shaping of fashion trends by French and Italian fabric companies. Industrial Marketing Management 35: 856-69.

Rinallo D., Golfetto F. (2011). Exploring the knowledge strategies of temporary cluster organizers: A longitudinal study of the EU fabric industry trade shows (1986-2006). Economic Geography 87: 453-76.

Rinallo D., Golfetto F. (2015). Internationalization and knowledge-based strategies of European trade show organizers in Asia: The case of Messe Frankfurt, in Bathelt H. and Zeng G. (eds.) Temporary Knowledge Ecologies: The Rise and Evolution of Trade Fairs in Asia-Pacific, Edward Elgar, 67-92.

Rinallo D., Golfetto F. (2017). The Orchestration of Innovation through Trade Shows: Insights from the concertation process in the clothing fabric industry, in $\mathrm{H}$.

Bathelt, P. Cohendet, S. Henn, L. Simon The Elgar Companion to Innovation and Knowledge Creation, Edward Elgar, forthcoming.

Rinallo D., Golfetto F., Borghini S. (2007). The influence of occupational communities on buyer behavior. $23^{\text {rd }}$ Industrial Marketing \& Purchasing Conference, Manchester. Available online:

<http://www.impgroup.org/paper_view.php?viewPaper=5930>, accessed 4 April 2015.

Rinallo D., Golfetto F., Borghini S. (2008). Building market knowledge together: A netnographic study of online occupational communities. $24^{\text {th }}$ Industrial Marketing \& Purchasing Conference. Available online: <http://www.impgroup.org/paper_view.php?viewPaper=6709>, accessed 4 April 2015.

Rinallo D., Golfetto F., Gibbert M, (2006). Consocia et impera: How French and Italian fabric producers cooperate to affirm the "dominant design" in the fashion industry", in Gibbert, M., Durand, T. (eds) Strategic Networks, Strategic Management Society, Blackwell, Oxford.

Rosson P.J., Seringhaus F.H.R. (1995). Visitor and exhibitor interaction at industrial trade fairs. Journal of Business Research 32: 81-90.

Rothaermel, F.T. (2001a). Complementary assets, strategic alliances, and the incumbent's advantage: An empirical study of industry and firm effects in the biopharmaceutical industry. Research Policy 30: 1235-51.

Rothaermel, F.T. (2001b). Incumbent's advantage through exploiting complementary assets via interfirm cooperation. Strategic Management Journal 22 (6-7): 68799.

Sarmento M., Simões C., Farhangmehr M. (2015). Applying a relationship marketing perspective to B2B trade fairs: The role of socialization episodes. Industrial Marketing Management 21 (3): 131-41.

Sashi C.M., Perretty J. (1992). Do trade shows provide value? Industrial Marketing 
Management 21 (3): 249-55.

Schau H.J., Muñiz, A.M., Arnould E. (2009). How brand community practices create value. Journal of Marketing 73: 30-51.

Scott A.J. (1998). Regions and the World Economy: The Coming Shape of Global Production, Competition, and Political Order. Oxford, New York: Oxford University Press.

Seringhaus F.H.R, Rosson P.J. (1994). International trade fairs and foreign market involvement: Review and research directions. International Business Review 3 (3): 311-29.

Seringhaus F.H.R., Rosson P.J. (1998). Management and performance of international trade fair exhibitors: Government stands vs independent stands. International Marketing Review 15 (5): 394-412.

Seringhaus F.H.R., Rosson P.J. (2001). Firm experience and international trade fairs. Journal of Marketing Management 17 (7-8): 877-901.

Sharlang A., Balogh P. (1996). The value of nonselling activities at international trade shows. Industrial Marketing Management 25 (1): 59-66.

Shipley D., Wong K.S. (1993). Exhibiting strategy and implementation. International Journal of Advertising 12 (2): 117-28.

Shoham A. (1992). Selecting and evaluating trade shows. Industrial Marketing Management 21 (4): 335-41.

Shoham A. (1999). Performance in trade shows and exhibitions: A synthesis and directions for future research. Journal of Global Marketing 12 (3): 41-57.

Skallerud K. (2010). Structure, strategy and performance of exhibitors at individual booths versus joint booths. Journal of Business \& Industrial Marketing 25 (4): 259-67.

Smith T.M., Gopalakrishna S., Smith P.M. (2004). The complementary effect of trade shows on personal selling. International Journal of Research in Marketing 21 (1): 61-76.

Storper M., Venables A.J. (2004). Buzz: Face-to-face contact and the urban economy. Journal of Economic Geography 4: 351-70.

Sunley P. (2008). Relational economic geography: a partial understanding or a new paradigm? Economic Geography 84 (1): 1-26.

Szulanski G. (2000). The process of knowledge transfer: A diachronic analysis of stickiness. Organizational Behavior and Human Decision Process 82 (1): 9-27.

Tanner J.F. Jr. (2002). Leveling the playing field: Factors influencing trade show success for small companies. Industrial Marketing Management 31 (3): 229-39.

Tanner J.F. Jr, Chonko L.B. (1995). Trade show objectives, management, and staffing practices. Industrial Marketing Management 24: 257-64.

Teece D.J. (1986). Profiting from technological innovation: Implications for 
integration, collaboration, licensing and public policy. Research Policy 15: 285305.

Torre A., Rallet A. (2005). Proximity and localization. Regional Studies 39: 47-59.

Uzzi B. (1997). Social structure and competition in interfirm networks: The paradox of embeddedness. Administrative Science Quarterly 42: 35-67.

Vendrusculo, F.D.C. (2016). The role of trade fairs in the Brazilian health industry complex. Annual Meeting of the Association of American Geographers, San Francisco.

Verlegh P.W.J., Steenkamp J.-B.E.M. (1999). A review and meta-analysis of countryof-origin research. Journal of Economic Psychology 20 (5): 521-46.

Von Hippel E. (1994). "Sticky" information and the locus of problem solving: Implications for innovation. Management Science 40 (4): 429-39.

Williams J.D., Gopalakrishna S., Cox J.M. (1993). Trade show guidelines for smaller firms. Industrial Marketing Management 22: 265-75.

Yeung H.W. (2005). Rethinking relational economic geography. Transactions of the Institute of British Geographers 30: 37-51.

Yin R.K. (1984). Case study research: Design and methods. Beverly Hills: Sage Publications.

Zerbini F., Golfetto F., Gibbert M. (2007). Marketing of competence: Exploring the resource-based content of value-for-customers through a case study analysis. Industrial Marketing Management 36: 784-98.

Zerbini F., Borghini S. (2012). Release capacity in the vendor selection process. Journal of Business Research 68: 405-14. 


\section{Figures}

Figure 1: Trade Shows as Temporary Clusters and Relationships with Permanent Clusters

$\begin{aligned} & \text { Permanent cluster } \\ & \text { (before trade fair) }\end{aligned}$
B $\begin{aligned} & \text { Temporary cluster } \\ & \text { (during trade fair) }\end{aligned}$
region
$\begin{aligned} & \text { actors, firms } \\ & \text { interpretative schemes }\end{aligned}$

Source: Bathelt and Schuldt, 2008, p.856. 
Figure 2: Typology of Trade Shows According to Exhibitor/Visitor Origin

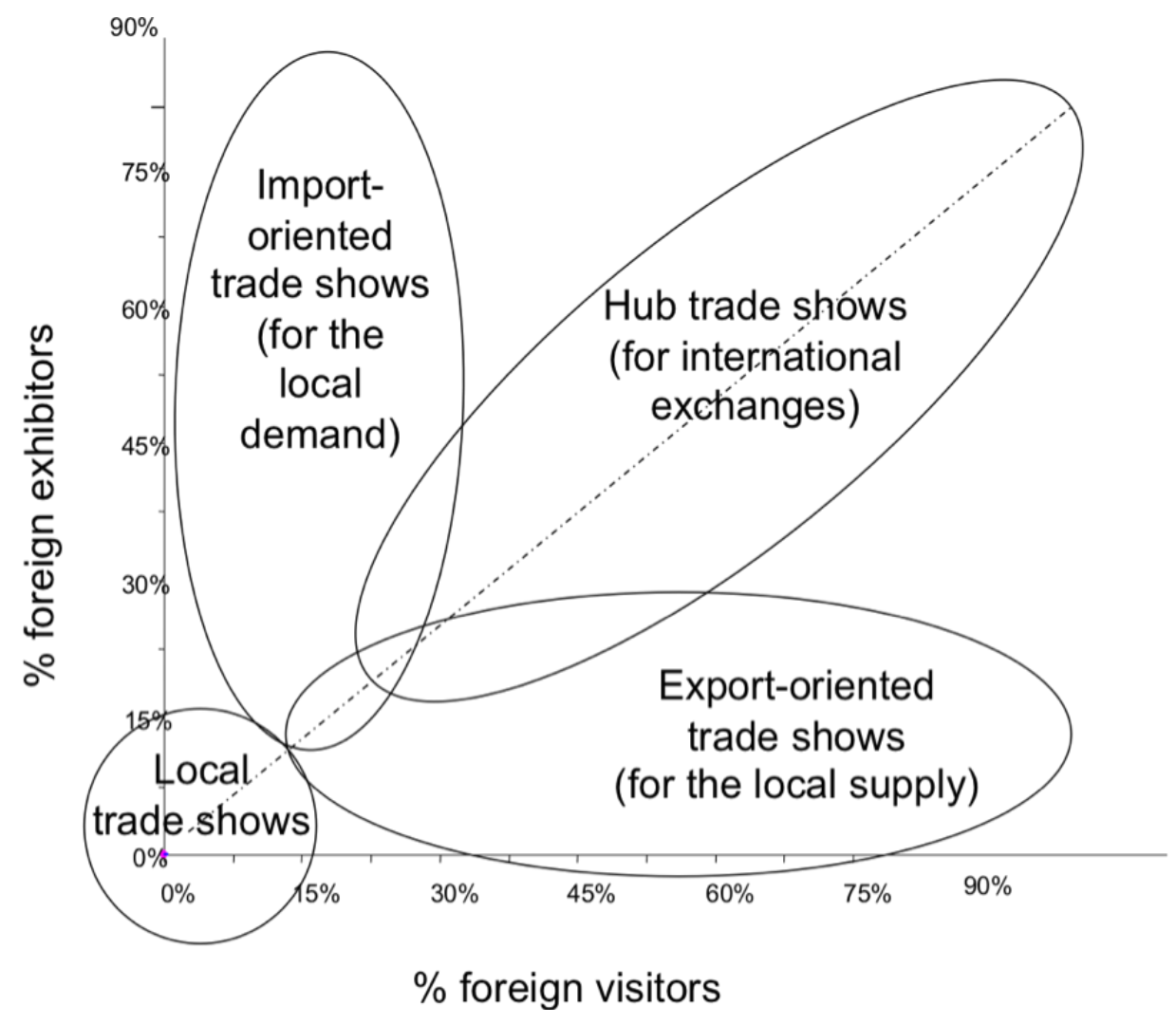

Source: Adapted from Rinallo and Golfetto, 2011. 


\section{Tables}

Table 1: Trade Shows in Industrial Marketing and Economic Geography:

Key Differences and Areas of Convergence

\begin{tabular}{|c|c|c|}
\hline $\begin{array}{l}\text { Category of } \\
\text { Comparison }\end{array}$ & Industrial Marketing & Economic Geography \\
\hline Metaphor & Temporary marketplaces & Temporary clusters \\
\hline $\begin{array}{l}\text { Reasons for } \\
\text { interest }\end{array}$ & $\begin{array}{l}\text { Important promotional tools for } \\
\text { industrial marketers }\end{array}$ & $\begin{array}{l}\text { Missing links between internal } \\
\text { cluster processes and external } \\
\text { agents and knowledge pools }\end{array}$ \\
\hline Key concerns & $\begin{array}{l}\text { Mostly measuring and } \\
\text { maximizing trade show results }\end{array}$ & $\begin{array}{l}\text { Understanding learning } \\
\text { processes occurring at and } \\
\text { facilitated by trade shows }\end{array}$ \\
\hline $\begin{array}{l}\text { Theoretical } \\
\text { underpinnings }\end{array}$ & $\begin{array}{l}\text { Mostly empirical generalizations } \\
\text { in marketing } \\
\text { Some studies focusing on } \\
\text { exhibitor/visitor interaction, } \\
\text { theoretically grounded in the } \\
\text { Industrial Marketing and } \\
\text { Purchasing (IMP) research } \\
\text { tradition }\end{array}$ & $\begin{array}{l}\text { Relational economic } \\
\text { geography (in particular, the } \\
\text { local buzz and global } \\
\text { pipelines model) }\end{array}$ \\
\hline $\begin{array}{l}\text { Key actors } \\
\text { investigated }\end{array}$ & Mostly exhibitors & Exhibitors and visitors \\
\hline $\begin{array}{l}\text { Areas of } \\
\text { convergence }\end{array}$ & $\begin{array}{l}\text { Increased attention to learning as } \\
\text { a dimension of trade shows' } \\
\text { performance } \\
\text { Attention to organizers and } \\
\text { collective marketing }\end{array}$ & $\begin{array}{l}\text { Increased attention on market- } \\
\text { related learning processes at } \\
\text { trade shows } \\
\text { Attention on organizers and } \\
\text { their knowledge-based } \\
\text { strategies }\end{array}$ \\
\hline
\end{tabular}


Table 2: Potential Contributions of Economic Geography (EG) Perspectives to Industrial Marketing (IM) Research on Trade Shows

\begin{tabular}{|c|c|c|c|}
\hline $\begin{array}{l}\text { Streams of } \\
\text { Research in } \\
\text { IM }\end{array}$ & Focus & $\begin{array}{l}\text { Examples of Related } \\
\text { Research in IM }\end{array}$ & EG Contributes to a Better Understanding of: \\
\hline $\begin{array}{l}\text { Learning and } \\
\text { resource } \\
\text { interaction at } \\
\text { trade shows }\end{array}$ & $\begin{array}{l}\text { Interactive learning and } \\
\text { resource development } \\
\text { facilitated by trade shows }\end{array}$ & $\begin{array}{l}\text { Borghini et al., 2006; Li, } \\
\text { 2006, 2007; Rinallo et al., } \\
\text { 2010; Zerbini and Borghini, } \\
\text { 2012; Zerbini et al., } 2007 \\
\end{array}$ & $\begin{array}{l}\text { - Initial and recurring resource interactions facilitated by trade shows } \\
\text { and their ongoing impacts on business relationships } \\
\text { The role that trade shows play in the interaction between resources } \\
\text { within and across organizational and spatial divides }\end{array}$ \\
\hline $\begin{array}{l}\text { Exhibitor } \\
\text { performance }\end{array}$ & $\begin{array}{l}\text { Measuring trade show } \\
\text { results and identifying their } \\
\text { determinants }\end{array}$ & $\begin{array}{l}\text { Borghini et al., 2006; } \\
\text { Geigenmüller and Bettis- } \\
\text { Outland, 2012; } \\
\text { Gopalakrishna et al., 2010; } \\
\text { Munuera and Ruiz, 1999; } \\
\text { Rinallo and Golfetto, 2006, } \\
\text { 2015; Tafesse, 2014 }\end{array}$ & $\begin{array}{l}\text { - Learning as outcome of trade show participation } \\
\text { - Trade show organizers, their relationships with exhibitors and visitors, } \\
\text { and their impact on exhibitor performances } \\
\text { Trade shows as meeting places of occupational communities, the } \\
\text { practices through which these communities create value and the ways } \\
\text { in which firms can benefit from these practices } \\
\text { - Theoretical sampling in trade show performance studies, as results are } \\
\text { contingent on the typology of trade show examined (e.g., import vs. } \\
\text { export-oriented trade shows) and its geographical context (e.g., } \\
\text { developed vs. developing countries) }\end{array}$ \\
\hline $\begin{array}{l}\text { Trade shows } \\
\text { as collective } \\
\text { marketing } \\
\text { instruments }\end{array}$ & $\begin{array}{l}\text { Trade shows as collective } \\
\text { marketing/branding/export } \\
\text { promotion instruments for } \\
\text { territorial and other } \\
\text { typologies of networks }\end{array}$ & $\begin{array}{l}\text { Rinallo and Golfetto, 2006; } \\
\text { Seringhaus and Rosson, } \\
\text { 1998; Skallerud, } 2010\end{array}$ & $\begin{array}{l}\text { - The nation brand building role of trade shows } \\
\text { - The impact of trade shows on the innovation trajectories of local and } \\
\text { national industries } \\
\text { - The relationships between industrial clusters and trade shows, which } \\
\text { are sometimes dysfunctional } \\
\text { - Collective trade show participation and export promotion from a } \\
\text { knowledge-based perspective } \\
\text { - Impact of globalization on trade shows and their underlying industries, } \\
\text { which affects the lifecycles of individual events and the evolution of } \\
\text { continental trade show platforms. }\end{array}$ \\
\hline
\end{tabular}


Table 3: Trade Shows as a Platform for Resource Interaction

\begin{tabular}{|c|c|c|}
\hline $\begin{array}{l}\text { Resource } \\
\text { Types }\end{array}$ & Definition & Role of Trade Shows \\
\hline Products & $\begin{array}{l}\text { Combination of } \\
\text { goods and services } \\
\text { that are exchanged } \\
\text { by organizational } \\
\text { units or in the } \\
\text { context of business } \\
\text { relationships }\end{array}$ & $\begin{array}{l}\text { At trade shows, firms showcase products } \\
\text { and prototypes to current and potential } \\
\text { business partners } \\
\text { Trade show dates set deadlines for } \\
\text { developing innovations, forcing } \\
\text { organizational units to cooperate under time } \\
\text { pressures }\end{array}$ \\
\hline Facilities & $\begin{array}{l}\text { Resources that are } \\
\text { employed to } \\
\text { develop, } \\
\text { manufacture, } \\
\text { promote, and } \\
\text { transport resources, } \\
\text { such as equipment, } \\
\text { plants, warehouses, } \\
\text { and exhibition } \\
\text { outlets }\end{array}$ & $\begin{array}{l}\text { Stands at trade shows are promotional } \\
\text { facilities whose design affect interaction } \\
\text { with customers and other business partners } \\
\text { Other resources (e.g. products, human } \\
\text { resources, equipment, etc.) are physically } \\
\text { present or represented (e.g. multimedia } \\
\text { representation of plants) as signals of firm } \\
\text { competence }\end{array}$ \\
\hline $\begin{array}{l}\text { Organizational } \\
\text { units }\end{array}$ & $\begin{array}{l}\text { Divisions, } \\
\text { departments, } \\
\text { informal groups, } \\
\text { individuals, and } \\
\text { other parts of an } \\
\text { organization }\end{array}$ & $\begin{array}{l}\text { At trade shows, organizational units } \\
\text { periodically get together and use the } \\
\text { opportunity for cross-unit interaction } \\
\text { Trade shows provide organizational units } \\
\text { with the opportunity to observe/interact } \\
\text { with customers, competitors, and other } \\
\text { actors }\end{array}$ \\
\hline $\begin{array}{l}\text { Inter- } \\
\text { organizational } \\
\text { relationships }\end{array}$ & $\begin{array}{l}\text { Long-term } \\
\text { relationships with } \\
\text { firms or other } \\
\text { typologies of an } \\
\text { organization }\end{array}$ & $\begin{array}{l}\text { Trade shows provide opportunities to } \\
\text { identify and select new partners } \\
\text { Trade shows also provide an opportunity to } \\
\text { interact periodically with current business } \\
\text { partners and some of their resources } \\
\text { (products, organizational units, etc.) }\end{array}$ \\
\hline
\end{tabular}

Source: Our elaboration, based on the 4R Model (Håkansson and Waluszewski, 2002) 